\title{
OBSERVATION OF ATTEMPTED
} PREDATION OF A WHOLLY

\section{OPOSSUM (Caluromys derbianus) BY A} TAYRA (Eira barbara) DURING DAYLIGHT IN BELIZE

\section{Gerardo Ceballos}

Instituto de Ecologia, Universidad Nacional Autonoma de Mexico, CP 04510, Ciudad de Mexico. Autor de correspondencia: Gerardo Ceballos: gceballo@ecologia.unam.mx

\section{Abstract}

I describe here the first observation of an attempted predation of a wholly opossum (Caluromys derbianus) by a tayra (Eira barbara). I observed the incident in the Macal River, close to San Ignacio town in west central Belize.

Key words: predation, tayra, wholly opposum, Belize.

Tayras (Eira barbara) are opportunistic predators that feed on a large number of vertebrates, invertebrates, and fruits of plants such as those of Cecropia trees and coffee (Bezerra et al., 2009; Ceballos, 2014; Defler, 1980). They are formidable terrestrial and scansorial predators, that extremely agile both in the ground and among the branches of trees (Presley, 2000). There are relatively few observations of tayras preying upon vertebrates in the wild. Reported predation or attempted predation of tayras include a variety of vertebrates such as brocket deer (Mazama sp), laughing falcon nestling (Herpetoteres cachinans), rufous-naped tamarin (Saguinus oedipus), red-handed tamarin (Saguinus midas), capuchin monkey (Cebus appella), squirrel monkey (Saimiri sciuerus), common marmoset (Callithrix jacchus), agouti (Dasyprocta punctata), pale-throated three-toed sloth (Bradypus tridactylus), cottontail rabbit (Sylvilagus brasiliensis), yacare (Caiman crocodilus), and green iguanas (Iguana iguana) among other species (e.g. Bezerra et al., 2009; Caluro, 2000; Campos and Mourão, 2015; Galef et al., 1976).

I report here the attempted predation of a wholly opossum (Caluromys derbianus) by a tayra (Eira barbara). On December 26 2016, I was cannoning in the Macal River upstream from the towns of Santa Elena and San Ignacio in the Cayo District of west - central Belize (Figure 1). 
I boarded the canoe close to the San Antonio town around 10:30 AM. The river was about $80 \mathrm{~m}$ wide and its margins were covered by a semi-green rainforest (Figure 2). The tallest trees were about 30 - 40 meters including Ceiba (Ceiba sp), guanacaste (Enterolobium cyclocarpum), and Fig (Ficus sp) trees, among many other species. Alone the riverbank I saw proboscis bats (Rhynchonycteris naso), Yucatan grey squirrels (Sciurus yucatanicus), green iguanas (Iguana iguana), and heard black howler monkeys (Allouatta pigra). There were many species of birds such as Keel-billed toucan (Rhamphastos sulfuratus), collared aracari (Pteroglossus torquatus), and white-collared manakin (Manacus candel).
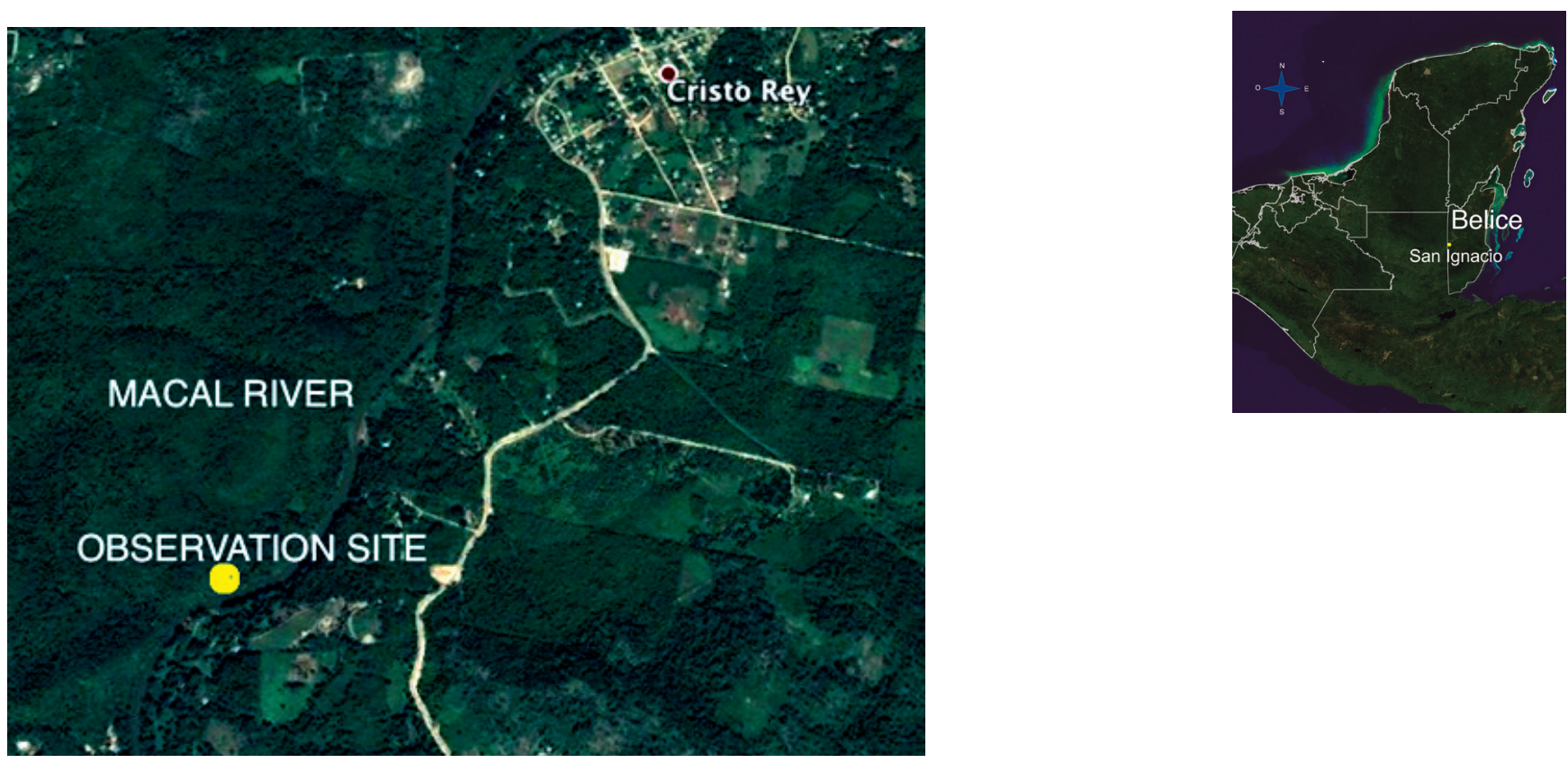

Figure 1. Location of the observation site in the Macal River, Cayo District, Belize. Photo: Gerardo Ceballos.

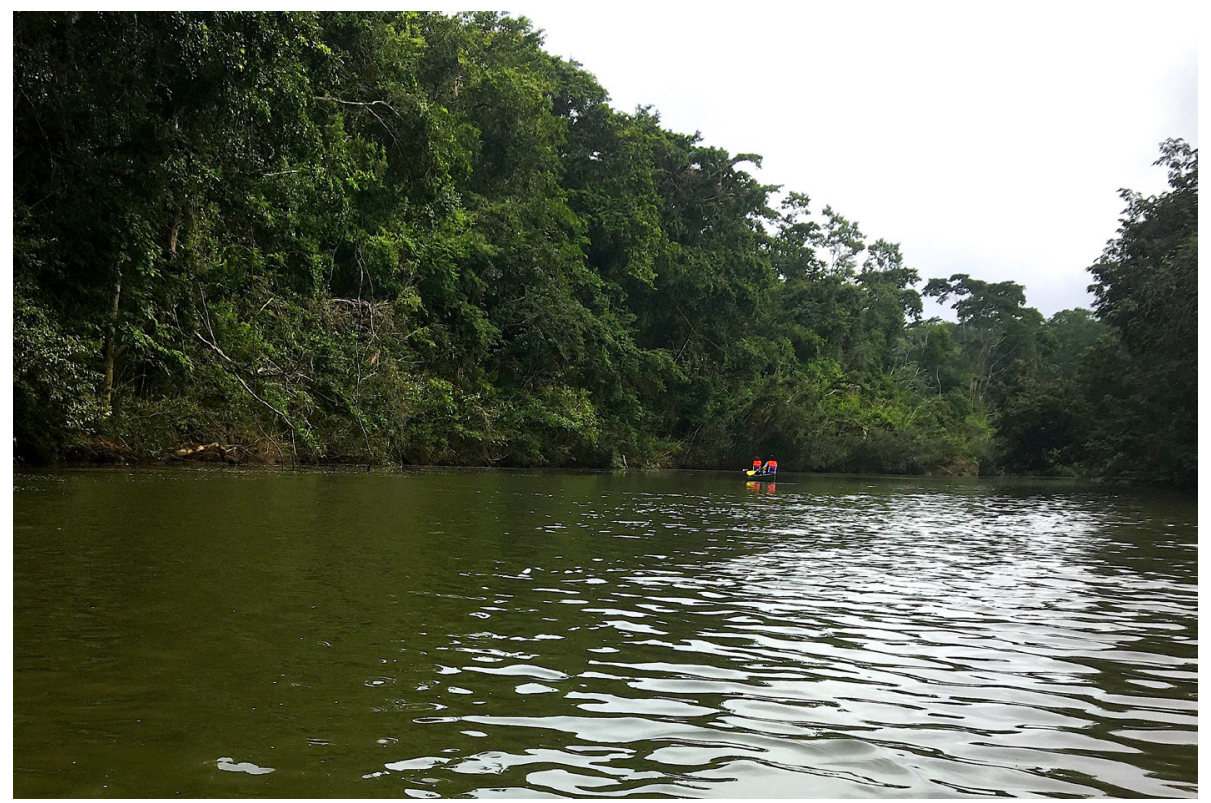

Figure 2. Macal River close to the observation site. Photo: Gerardo Ceballos. 
The day was cloudy and in the two-hour canoeing trip it slightly rained for about 10 minutes. Around 11:51 AM I and the other 4 people in my party suddenly heard a lot of noise and observed chaotic movements of the branches of some trees on the left margin of the river bank (approximate location: 170 06' 51.40" N, 890 04' 07.64"). The temperature was approximately $20^{\circ} \mathrm{C}$. The forest was dense and the tallest trees were estimated to be around $30 \mathrm{~m}$ height. We saw a wholly opossum (Caluromys dervianus) running away from a tayra. Our presence disturbed the tayra and the opossum escaped climbing a very thin vine, likely no more that $2 \mathrm{~cm}$ diameter. As we got closer the riverbank, the tayra climb down the tree and ran away (Figure 3). From what I observed, it seem that the tayra had found the wholly opossum in its nest in a tree hollow and intended to prey upon it. Observing a tayra preying upon wholly opossum has not been reported before.

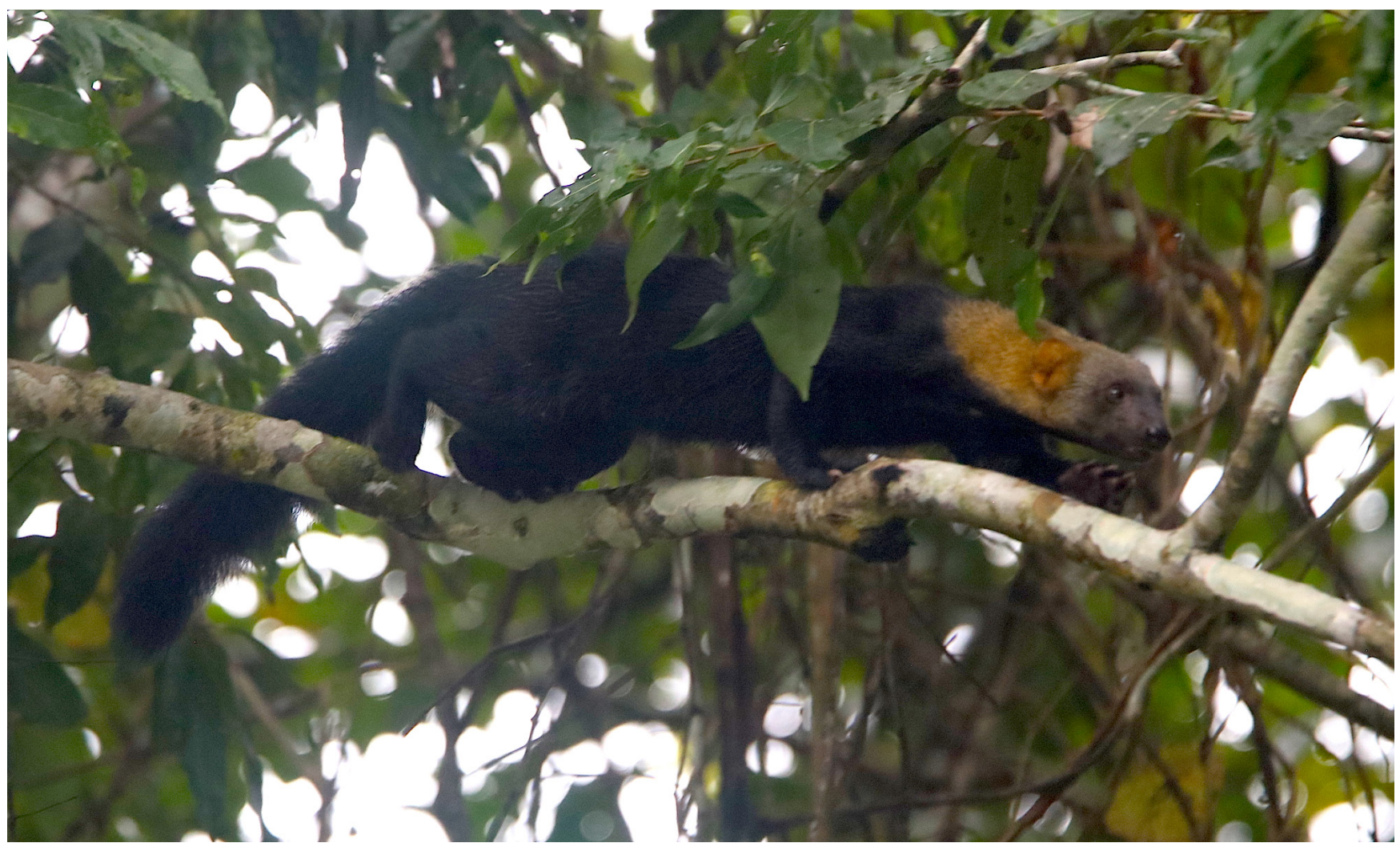

Figure 3. Tayra (Eira barbara) photographed after abandoning the attemted predation of the wholly opposum (Caluromys derbiabus). Photo: Gerardo Ceballos.

\section{LITERATURA CITED}

Bezerra, B.M., A.A. Barnett, A. Souto and G. Jones. 2009. Predation by the tayra on the common marmoset and the pale-throated three-toed sloth. Journal of Ethology, 27:91-96.

Calouro, A.M. 2000. Attempted predation on Brazilian rabbit (Sylvilagus brasiliensis Lagomorpha: Leporidae) by tayra (Eira barbara Carnivora: Procyonidae). Revista Biologia Tropical, 48, 267-268.

Campos, Z. and G. Mourão. 2015. Camera traps capture images of predators of Caiman crocodilus yacare eggs (Reptilia: Crocodylia) in Brazil's Pantanal wetlands. Journal of Natural History, 49: 977-982. 
Ceballos, G. 2014. Mammals of Mexico. John Hopkin Press, Baltimore.

Defler, T.R. 1980. Notes on interactions between the tayra (Eira barbara) and the white-fronted capuchin (Cebus albifrons). Journal of Mammalogy, 61:156-156.

Galef, B.G., R.A. Mittermeier and R.C. Bailey. 1976. Predation by the tayra (Eira barbara). Journal of Mammalogy, 57:760-761.

Presley, S.J. 2000. Eira barbara. Mammalian species, 1-6. 